\title{
PetroQUANT - autorski program komputerowy do wyliczania składu mineralnego i chemicznego skał
}

\begin{abstract}
W artykule zaprezentowano autorski program komputerowy przeznaczony do wyliczania składu mineralnego i chemicznego skał. Omówiono jego najważniejsze funkcjonalności i przypadki użycia. Poruszono zagadnienie innowacyjnego podejścia do udostępniania tego typu programów w formie aplikacji internetowej z wykorzystaniem nowoczesnego narzędzia, jakim są usługi sieciowe (web services). Zaprezentowano programowe możliwości porównywania (korelacji) otrzymanych wyników z wynikami uzyskanymi za pomocą urządzenia XRF (X-ray fluorescence) w formie tabelarycznej i graficznej (wykres).
\end{abstract}

Słowa kluczowe: PetroQUANT, mineralogia, XRD, XRF, program komputerowy, usługi sieciowe.

\section{PetroQUANT - proprietary computer program calculating mineral and chemical composition of rocks}

In the article a proprietary computer program calculating mineral and chemical composition of rocks was presented. It discusses the major features and use cases. The issue of innovative approach to share these kinds of programs (as web applications) using web services was raised. The capabilities of correlation of received results with X-ray fluorescence in tabular and graphical (chart) form were presented.

Key words: PetroQUANT, mineralogy, XRD, XRF, computer program, web services.

\section{Wstęp}

Profilowania geofizyczne są od lat głównym narzędziem wykorzystywanym przy poszukiwaniu złóż węglowodorów przez firmy naftowe. Poszerzenie zestawu profilowań geofizycznych o coraz nowocześniejsze i precyzyjniejsze sondy analizujące coraz szerszy zestaw składników chemicznych występujących w badanym ośrodku skalnym stwarza nowe możliwości analizy zmienności litologicznej przewiercanych skał [13]. W ślad za tym rosną również wymagania co do jakości i szczegółowości badań mineralogicznych wykonywanych w warunkach laboratoryjnych.

Jednym z nowych wyzwań jest coraz większa potrzeba precyzyjnej kompilacji wyników analizy składu mineralnego oraz chemicznego i wyznaczania na tej podstawie takich parametrów jak gęstość ośrodka czy współczynnik fotoelektryczny. Oba parametry mogą być zarówno mierzone w warunkach laboratoryjnych, jak i wyznaczane na bazie profilowań geofizycznych.
Wyliczanie powyższych parametrów na podstawie wyników badań mineralogicznych i chemicznych, które następnie można porównać $\mathrm{z}$ wartościami pomierzonymi, stanowi dodatkowo sposób kontroli wyników. Wykonywanie takich porównań z wykorzystaniem arkuszy kalkulacyjnych typu Excel sprawia jednak wiele problemów i zajmuje dużo czasu. Przykładem takiego rozwiązania może być program HandLens, działający jako makro Excela [3].

Pierwszym nasuwającym się rozwiązaniem problemu jest utworzenie programu komputerowego specjalnie przeznaczonego do tego celu. Programy tego typu funkcjonują już na rynku, ale możliwości ich wykorzystania są ograniczone. Jednym $z$ takich rozwiązań jest BESTMIN, opracowany na potrzeby firmy ChevronTexaco [13]. Program ten nie jest jednak udostępniany innym podmiotom badawczym $\mathrm{i}$ komercyjnym.

Instytut Nafty i Gazu - Państwowy Instytut Badawczy zdecydował się opracować swój własny program pozwala- 
jący przeliczać skład mineralny próbek na skład chemiczny i wyznaczać na tej podstawie różne parametry geofizyczne. Program PetroQUANT powstał w ramach współpracy po- między Zakładem Geofizyki Wiertniczej oraz Zakładem Informatyki Instytutu Nafty i Gazu - Państwowego Instytutu Badawczego.

\section{Dane wejściowe}

Z założenia standardowymi danymi wejściowymi do programu będą wyniki analizy ilościowej składu mineralnego uzyskane metodą dyfrakcji rentgenowskiej (XRD) - rysunek 1 . Wyliczony skład chemiczny (rysunek 2) będzie porównywany z wynikami pomiarów składu chemicznego wykonanych metodą fluorescencji rentgenowskiej (XRF) - rysunek 3.

\section{Dane wejściowe}

Wpisz jakie mineraly wchodzą w skład danej skały i podaj ich udział procentowy. Całkowity udział minerałów w
skale musi wynosic $100 \%$
Dodaj minerał
\begin{tabular}{|l|l|l|l|l|l|l|l|}
\hline Minerał & Crystobalit & - & Udział proc. & 30 & - \\
\hline Minerał & Aragonit & Udział proc. & 20 & - \\
\hline Minerał & Markasyt & - Udział proc. & 50 & + \\
\hline
\end{tabular}

Kliknij + aby dodać kolejny minerat

> Oblicz skład H Zapisz konfiguracje

Rys. 1. Dane wejściowe do programu PetroQUANT

Ilościowy skład mineralny skały wyliczany jest w Zakładzie Geofizyki Wiertniczej metodą Rietvelda [4, 6] przy pomocy programu komputerowego Siroquant, o udokumentowanej przydatności do analizy składu skał zawierających również minerały ilaste. Program ten był wykorzystywany przez zwycięzców konkursu Reynolds Cup, dotyczącego analizy ilościowej próbek zawierających minerały ilaste metodą XRD, nazwanego na część Boba Reynoldsa [5]. Konkurs ten został po raz pierwszy zorganizowany w 2000 roku przez Douglasa McCarty'ego (ChevronTexaco), Jana Środonia (PAN Kraków) oraz Dennisa Eberla (USGS) i odbywa się od tego czasu cyklicznie co dwa lata.

Podstawowy skład chemiczny próbek skał standardowo mierzony jest metodą fluorescencji rentgenowskiej. Zakład
Geofizyki Wiertniczej posiada przenośny spektrometr XRF, który umożliwia pomiary na rdzeniu wiertniczym bezpośrednio w magazynie rdzeniowym [8]. Pomiary można również wykonać na próbce sproszkowanej. Ponieważ jest to metoda nieniszcząca, tę samą próbkę można następnie wykorzystać do analizy składu mineralnego metodą XRD. Oba pomiary mogą być wykonywane niemal równocześnie, a ich wyniki można szybko ze sobą porównywać, otrzymując poszerzoną informację o składzie mineralnym próbki.

Mankamentem wykonywania pomiarów składu chemicznego za pomocą spektrometru przenośnego jest brak możliwości pomiaru sodu (Na). Przygotowywany program zakłada $\mathrm{w}$ związku z tym również możliwość wykorzystywania danych w dwóch opcjach: bez Na oraz z Na. Sód może być pomierzony spektrometrem stacjonarnym. Z użyciem omawianego programu interpretator potrafi sformatować dane bezpośrednio uzyskiwane z przenośnego spektrometru, podając wyniki analizy składu chemicznego albo w postaci tlenków, albo pierwiastków.

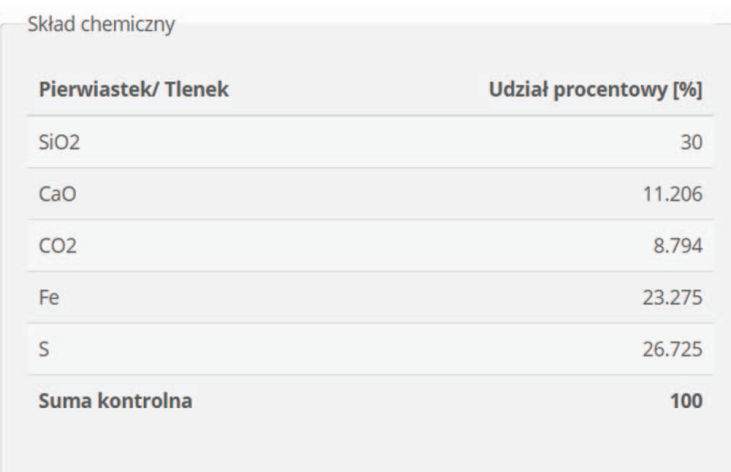

Rys. 2. Wyniki działania programu PetroQUANT - tablica

\section{Aplikacja internetowa - innowacyjne podejście}

Program PetroQUANT został zaprojektowany i zrealizowany jako aplikacja internetowa w architekturze klient-serwer. Takie niestandardowe podejście przy tego typu zastosowaniach ma sporo zalet. Po pierwsze - dostępność. Do aplikacji można mieć dostęp z dowolnego miejsca na świecie, dysponując jedynie łączem internetowym oraz jedną z popularnych przeglądarek internetowych. Zestawienie najpopularniejszych przeglądarek internetowych, które mogą być wykorzystane do obsługi programu PetroQUANT, przedstawia tablica 1.

Od urządzenia klienckiego (np. stacji roboczej) nie wymaga się dużych zasobów sprzętowych czy specjalnej wydajności, a takie wygórowane wymagania mają często inne programy branżowe. Dzieje się tak dlatego, że cała logika omawianej aplikacji odpowiedzialna za obliczenia działa po stronie serwera - to on bierze na siebie ciężar obliczeń, 
przesyłając jedynie wyniki, które są renderowane po stronie klienta do postaci tabel i wykresów.

Dzięki temu, dysponując maszyną serwerową o dużej mocy obliczeniowej, można zapewnić najwyższą jakość usługi wszystkim klientom. Program działa również niezależnie od systemu operacyjnego zainstalowanego na urządzeniu klienckim, a więc z PetroQUANT mogą korzystać użytkownicy posiadający na swoich komputerach systemy GNU/Linux, Windows czy MacOS. Klientem aplikacji nie musi być nawet desktop czy laptop - wystarczy jedno z popularnych urządzeń mobilnych, jak tablet czy smartfon. Oczywiście wielkość ekranu wpływa na komfort pracy z programem, jednak dzięki zastosowaniu techniki RWD (responsive web design) interfejs użytkownika potrafi się
Tablica 1. Najpopularniejsze przeglądarki internetowe [2]

\begin{tabular}{|l|c|}
\hline Nazwa przeglądarki & $\begin{array}{c}\text { Udział w rynku } \\
{[\%]}\end{array}$ \\
\hline Chrome & 72,5 \\
\hline Firefox & 16,3 \\
\hline IE & 5,3 \\
\hline Safari & 3,5 \\
\hline Opera & 1,0 \\
\hline Pozostałe & 1,4 \\
\hline Podsumowanie & 100,0 \\
\hline
\end{tabular}

dopasować do rozdzielczości, więc komfort pracy powinien być nadal relatywnie wysoki.

\section{Program PetroQUANT jako usługa sieciowa}

Usługa sieciowa to programistyczna realizacja pewnej funkcjonalności świadczonej (mówiąc w uproszczeniu) za pomocą sieci Internet. Innymi słowy, jest to programistyczna „czarna skrzynka” - program, który wykonuje pewną pracę, a którego zawartość nie jest istotna z punktu widzenia klienta tej usługi. Klienta interesuje jedynie sama funkcjonalność, a dowiaduje się o niej poprzez opis usługi, który powinien zawierać rzetelne informacje na temat rodzaju świadczonej usługi, danych wejściowych, jakich usługa się spodziewa (tzw. wsadu), oraz danych wyjściowych (wyniku).

Powyższe szczegóły zawiera język opisu usług WSDL (Web Services Description Language) [14]. Jest to oparty na XML-u język zawierający definicje metod oraz parametrów obsługiwanych przez projektowaną usługę. Plik przygotowany zgodnie ze standardem WSDL należy umieścić na serwerze w celu udostępnienia go klientom usługi. Dokument w formacie WSDL, choć mało czytelny dla użytkownika, stanowi bezcenne źródło informacji o usłudze dla komputerów. Wskazanie położenia dokumentu WSDL sprawia, że mechanizm SOAP automatycznie utworzy obiekt potrzebny do komunikacji z daną usługą oraz umożliwi programiście używanie tego obiektu w sposób analogiczny do lokalnych obiektów innych klas PHP. Istotą usług web services jest fakt, że sposób realizacji funkcjonalności usługi pozostaje ukryty (ukrywanie szczegółów implementacyjnych).

Największą zaletą stosowania usług internetowych jest możliwość korzystania z rozproszonych zasobów (programów udostępniających różne funkcjonalności) niezależnie od języka programowania, w którym są napisane, czy platformy sprzętowej, na której działają. Taka koncepcja tworzenia oprogramowania znana jest na świecie pod nazwą service-oriented architecture (SOA). W systemach informatycz- nych, które spełniają warunki architektury SOA, usługą sieciową jest każdy element oprogramowania posiadający niżej określone cechy:

- udostępnia pewną zamkniętą funkcjonalność,

- może działać niezależnie od innych części oprogramowania,

- posiada zdefiniowany interfejs do komunikacji,

- działa niezależnie od platformy programistyczno-sprzętowej.

Sięganie po usługi internetowe jest zasadne, gdy mamy dobrze zdefiniowany problem (np. autorski algorytm), który można przekształcić w program komputerowy. Chcemy, aby $\mathrm{z}$ tego programu mogli korzystać inni (darmowo lub odpłatnie), jednak wymagamy, aby szczegóły implementacyjne pozostały ukryte (ochrona własności intelektualnej).

Jedną z podstawowych zalet usług sieciowych, które skłoniły autorów programu do przybliżenia tego zagadnienia, jest możliwość świadczenia rozmaitych usług (np. wykorzystywanie autorskiego algorytmu, programu komputerowego czy specyficznych zestawów danych) w skali globalnej przy całkowitej ochronie własności intelektualnej. Jest to możliwe, gdyż komponenty usługowe działają zdalnie, czyli nie są fizycznie wręczane konsumentom usług.

Zauważmy na przykład, jak dzisiaj odbywa się proces przeliczania danych za pomocą autorskich programów komputerowych. W wielu przypadkach dane są dostarczane na nośnikach danych (CD, DVD, pamięć USB) lub za pośrednictwem poczty elektronicznej. Twórca programu wprowadza otrzymane dane do programu, uruchamia go i zwraca uzyskane wyniki tą samą drogą. Gdy jednak klient chce korzystać z programu bardzo często, taka sytuacja staje się kłopotliwa. Zdaniem autorów programu w niektórych uzasadnionych przypadkach proces ten można w pełni zautomaty- 
zować, co zaoszczędzi czas, z drugiej zaś strony, dzięki udostępnieniu programu w sieci Internet, pozwoli znacznie poszerzyć grono potencjalnych zainteresowanych daną usługą.

Częstym błędem jest mylenie usług web services z usługami świadczonymi w sieci Internet takimi jak strony WWW czy poczta elektroniczna. Oczywiście strona WWW może być interfejsem służącym do interakcji z użytkownikiem $\mathrm{w}$ ramach usługi sieciowej, jednak jest to sprawa drugorzędna [1]. Algorytm zaszyty w programie PetroQUANT spełnia wszystkie cechy wzorcowej usługi sieciowej. Zaprogramowany w taki sposób mógłby być z powodzeniem wykorzystany w architekturze SOA.

\section{Programistyczna realizacja aplikacji}

Program PetroQUANT został napisany w języku PHP w wersji 7.0.8 z wykorzystaniem szkieletu projektowego Silex [11] wraz z bibliotekami. Połączenie do serwera bazy danych realizowane jest za pośrednictwem biblioteki Doctrine [9], a konkretniej abstrakcyjnej warstwy Doctrine Database Abstraction Layer (DBAL), ulokowanej na szczycie PDO (PHP Data Objects). Posiada ona bardzo wygodny, bezpieczny i elastyczny interfejs programistyczny do komunikacji z najbardziej popularnymi relacyjnymi bazami danych. Innymi słowy, biblioteka DBAL ułatwia wykonywanie zapytań i realizację innych działań na bazie danych.

W celu oddzielenia logiki aplikacji od warstwy prezentacji autorzy wykorzystali bibliotekę Twig [10]. Jest to potężny i bardzo wydajny system szablonów odpowiadający za generowanie kodu HTML na podstawie danych wejściowych. Twig świetnie się sprawdza przy generowaniu kodu HTML po stronie serwera, jednak niektóre elementy aplikacji są renderowane po stronie przeglądarki internetowej. Na przykład generowanie wykresu prezentującego skład chemiczny odbywa się po stronie klienta, na podstawie danych przesłanych techniką AJAX (Asynchronous JavaScript and XML), za pomocą skryptów języka JavaScript. Autorzy programu wykorzystali również bibliotekę o otwartym kodzie źródłowym służącą do generowania wykresów - Chart.js (rysunek 3).

\section{Modelowanie architektury systemu}

Przed przystąpieniem do prac programistycznych autorzy stworzyli model architektury systemu z wykorzystaniem diagramów języka UML (Unified Modeling Language) [12]. Minimalny zestaw diagramów zawiera: diagram przypadków użycia, diagramy czynności oraz diagramy klas. Rysunek 4 prezentuje uproszczony diagram przypadków użycia dla jednego aktora, w tym przypadku użytkownika programu PetroQUANT.

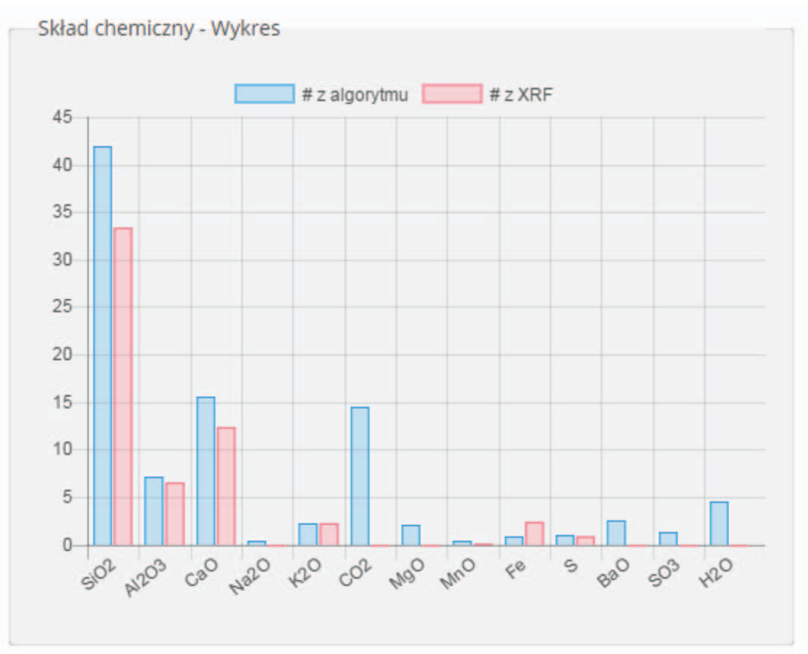

Rys. 3. Wyniki działania programu PetroQUANT - wykres

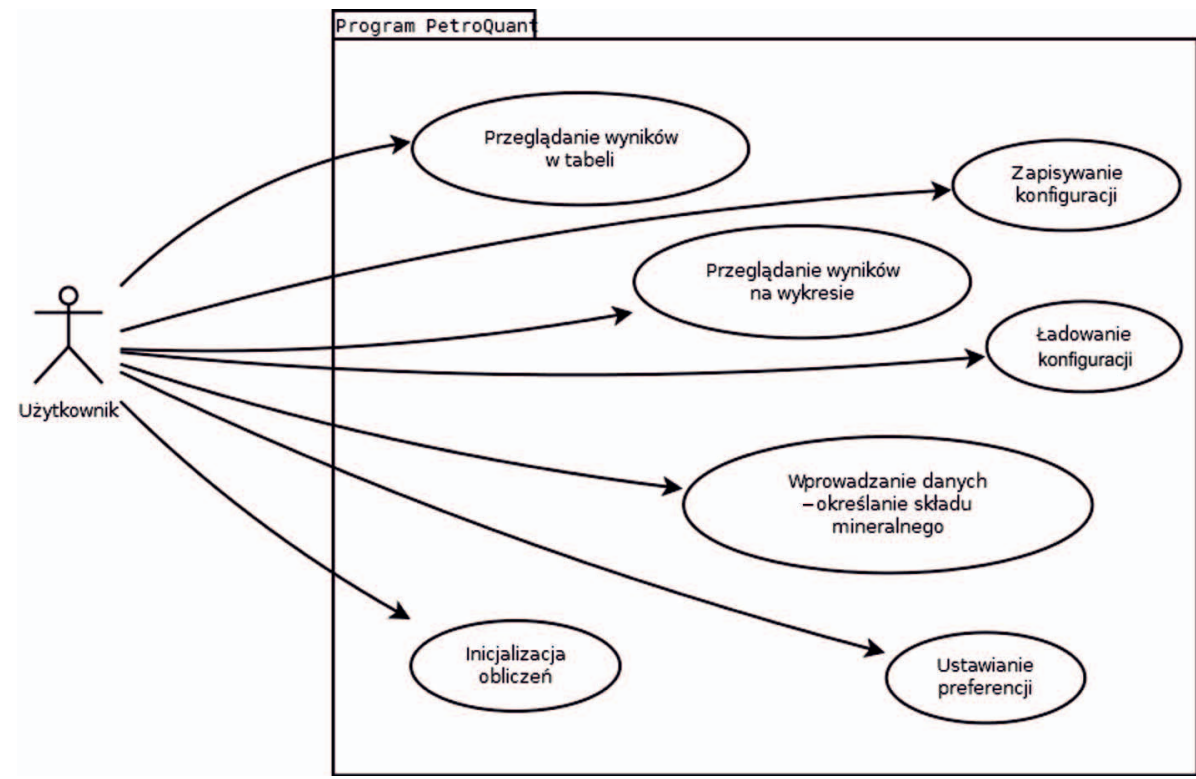

Rys. 4. Diagram przypadków użycia programu PetroQUANT

\section{Przygotowanie środowiska serwerowego}

Aplikacja prezentowana w niniejszej pracy łączy się ze zdalnym komputerem (serwerem) za pośrednictwem protokołów komunikacyjnych oraz sieci Internet. W tym celu autorzy przygotowali odpowiedni serwer oraz skonfigurowali na nim niezbędne usługi (programy działające w tle). Oto lista najważniejszych czynności, które należało wykonać:

1. Stworzenie maszyny wirtualnej. 
2. Instalacja i konfiguracja systemu operacyjnego Ubuntu 16.04.2 LTS (GNU/Linux 3.5.0-23-generic x86 64) [7].
3. Instalacja i konfiguracja serwera Apache.

4. Instalacja i konfiguracja serwera bazy danych MySQL.

\section{Podsumowanie}

Program komputerowy PetroQUANT został opracowany w ramach pracy statutowej w wyniku współpracy Zakładu Informatyki oraz Zakładu Geofizyki Wiertniczej Instytutu Nafty i Gazu - Państwowego Instytutu Badawczego. Przy jego projektowaniu założono na wstępie, że ma on dawać możliwość łatwej modyfikacji parametrów oraz dodawania nowych funkcji obliczeniowych, czyli umożliwiać adaptację do zmieniających się potrzeb potencjalnych odbiorców.

System komputerowy PetroQUANT został opracowany jako aplikacja internetowa w języku PHP7, wykorzystująca także skrypty języka JavaScript, kaskadowe arkusze stylów CSS3, język znaczników HTML5 oraz bazę danych MySQL. Zakłada się, że system powinien być instalowany na serwerze z systemem operacyjnym GNU/Linux, z działającym serwerem http Apache oraz silnikiem baz danych MySQL.

Z punktu widzenia funkcjonalności głównym zadaniem programu PetroQUANT, na obecnym etapie jego tworzenia, jest przeliczanie składu mineralnego skał na ich skład chemiczny oraz porównywanie wyników obliczeń z wynikami uzyskanymi za pomocą urządzenia XRF. Prototyp programu został przetestowany przez pracowników Zakładu Geofizyki Wiertniczej Instytutu Nafty i Gazu - Państwowego Instytutu Badawczego na podstawie próbek dolnopaleozoicznych $\mathrm{z}$ basenu bałtyckiego. Zaprezentowana aplikacja jest wersją testową, a niniejszy artykuł nie zawiera pełnego opisu jej funkcjonalności. Celem programu było przede wszystkim pokazanie możliwości wykorzystania usług sieciowych jako aplikacji obliczeniowych.

Prosimy cytować jako: Nafta-Gaz 2016, nr 12, s. 1049-1053, DOI: 10.18668/NG.2016.12.06

Artykuł nadesłano do Redakcji 7.11.2016 r. Zatwierdzono do druku 25.11.2016 r.

Artykuł powstał na podstawie pracy statutowej pt. Opracowanie algorytmu wyliczajacego skład mineralny skał na podstawie wyników analizy składu chemicznego - praca INiG - PIB na zlecenie MNiSW; nr zlecenia: 0018/SP/16/01, nr archiwalny: DK-4100-18/16.

\section{Literatura}

[1] Badowski J.: Ustugi sieciowe jako narzędzie do nowoczesnego i bezpiecznego udostepniania ustug obliczeniowych $i$ badawczych. Nafta-Gaz 2016, nr 1, s. 58-65.

[2] Browser statistics. Strona internetowa W3Schools. http:// www.w3schools.com/browsers/ (dostęp: 24.10.2016).

[3] Eberl D.D.: User's guide to HandLens - A computer program that calculates the chemistry of minerals in mixtures. U.S. Geological Survey Open-File Report 2008, 2008-1244, 27 s.

[4] Kowalska S.: Określanie ilościowego składu mineralnego skat zawierajacych mineraty ilaste metoda Rietvelda. Nafta-Gaz 2013, nr 12, s. 894-902.

[5] Omotoso O., McCarty D.K., Hillier S., Kleeberg R.: Some successful approaches to quantitative mineral analysis as revealed by the $3 r d$ Reynolds Cup contest. Clays and Clay Minerals 2006, vol. 54, no. 6, s. 748-760.

[6] Rietveld H.M.: A profile refinement method for nuclear and magnetic structures. Journal of Applied Crystallography 1969 , vol. 2, s. 65-71.

[7] Scale out with Ubuntu Server. Strona internetowa systemu Ubuntu. https://www.ubuntu.com/server (dostęp: 24.10.2016).

[8] Skupio R.: Wykorzystanie przenośnego spektrometru XRF do

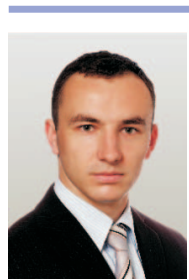

Mgr inż. Jakub BADOWSKI

Asystent w Zakładzie Informatyki.

Instytut Nafty i Gazu - Państwowy Instytut Badawczy

ul. Lubicz 25 A

31-503 Kraków

E-mail:jakub.badowski@inig.pl pomiarów składu chemicznego skat. Nafta-Gaz 2014, nr 11, s. 771-777.

[9] Strona internetowa projektu Doctrine. http://www.doctrine-project.org/ (dostęp: 24.10.2016).

[10] Strona internetowa systemu szablonów Twig. http://twig.sensiolabs.org/ (dostęp: 24.10.2016).

[11] Strona internetowa szkieletu projektowego Silex. http://silex.sensiolabs.org/ (dostep: 24.10.2016).

[12] Śmiałek M.: Zrozumieć UML 2.0. Metody modelowania obiektowego. Gliwice, Helion, 2005.

[13] Środoń J., Mystkowski K., McCarty D.K., Drits V.A.: BESTMIN: a computer program for refining the quantities and the chemical composition of clays and other mineral components of fine-grained rocks. International Conference „Clays and Clay Minerals”, Pushchino, Russia 2006, Abstracts, s. 41.

[14] XML WSDL. Strona internetowa W3Schools. http://www. w3schools.com/xml/xml_wsdl.asp (dostęp: 24.10.2016).

[15] Zorski T., Jarzyna J., Derkowski A., Środoń J.: Geofizyka otworowa $w$ dobie poszukiwań gazu w tupkach - przeglad metod pomiarowych. Przegląd Geologiczny 2013, vol. 61, nr 7, s. 424-434.

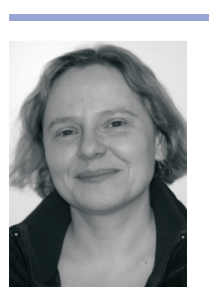

Dr Sylwia KOWALSKA

Adiunkt w Zakładzie Geofizyki Wiertniczej.

Instytut Nafty i Gazu - Państwowy Instytut Badawczy

ul. Lubicz 25 A

31-503 Kraków

E-mail: sylwia.kowalska@inig.pl 